\title{
Thymic neuroendocrine tumor
}

INSERM

\section{Source}

INSERM. (1999). Orphanet: an online rare disease and orphan drug data base. Thymic neuroendocrine tumor. ORPHA:97289

Thymic endocrine tumor is a rare, malignant, primary thymic neoplasm originating from neuroendocrine cells, presenting as a mass within the anterior mediastinum. Patients typically present with nonspecific symptoms, such as chest pain, cough, shortness of breath, or in some cases, superior vena cava syndrome, although patients could be asymptomatic during the early stages or present with multiple endocrine neoplasia type I. Ectopic production of ACTH and serotonin can lead to Cushing syndrome and carcinoid syndrome, respectively. 